\title{
Association of Biochemical Parameters with Renal Functions of End Stage Renal Disease (ESRD) Patients of Bangladesh
}

Md Shohel Hossain ${ }^{1 *}$, Khondokar Md Akter-Uz-Zaman', Mohammad Nurul Amin ${ }^{2}$, Rubel Ahammed ${ }^{1}$, Md Emdadul Haque $^{1}$, Md Ibrahim $^{2}$, Md Lukman Hakim ${ }^{3}$, Dos Mohammad ${ }^{4}$, Md Alamgir Kabir ${ }^{5}$, Md Saiful Islam Arman ${ }^{1}$, Ummay Hanni ${ }^{2}$ and Mohammad Safiqul Islam ${ }^{*}$

${ }^{1}$ Department of Pharmacy, Manarat International University, Dhaka, Bangladesh

${ }^{2}$ Department of Pharmacy, Atish Dipankar University of Science and Technology, Dhaka, Bangladesh

${ }^{3}$ Department of Pharmaceutical Sciences, North South University, Dhaka, Bangladesh

${ }^{4}$ Department of Applied Chemistry and Chemical Engineering, Noakhali Science and Technology University, Dhaka, Bangladesh

${ }^{5}$ Department of Psychology, University of Dhaka, Dhaka, Bangladesh

${ }^{6}$ Department of Pharmacy, Noakhali Science and Technology University, Noakhali, Bangladesh

\begin{abstract}
Biochemical parameters are greatly influenced by genetic, physiological and environmental factors. Regional data is essential to establish a relationship between End stage renal disease (ESRD) and biochemical parameters. In Bangladesh, there is not any established research data on biochemical parameters of ESRD patient. The present study was a case control study with 500 ESRD patients and equal number of healthy volunteers (controls). Sociodemographic, anthropometric and clinical data of both patients and controls were collected. Serum biochemical parameters were analyzed by laboratory test. Statistical software package SPSS were used for independent sample t-test and Pearson's correlation test. Our study found that serum creatinine, blood urea nitrogen (BUN) and serum uric acid were significantly higher $(p<0.05)$ and serum potassium were significantly lower in ESRD patient as compared to control subjects $(p<0.05)$. But serum chloride, serum sodium and serum calcium level were in the normal range. Pearson correlation analysis reveals that serum creatinine and serum chloride was inversely correlated with GFR (glomerular filtration rate) in both patient and control groups. This study explored that ESRD patients have higher level of serum creatinine, BUN and serum uric acid but lower level of serum potassium than normal patient. Routine investigation of serum biochemical parameters may help to prevent ESRD complication.
\end{abstract}

Keywords: Serum creatinine; Blood urea nitrogen (BUN); End Stage Renal Disease (ESRD)

\section{Introduction}

ESRD or end stage renal disease means established kidney failure when GFR $<15 \mathrm{ml} / \mathrm{min} / 1.73 \mathrm{~m}^{2}$ and need permanent renal replacement therapy or dialysis [1]. Chronic kidney disease (CKD) affects about $10 \%$ of the population worldwide and millions of them are dying every year due to lack of treatment [2]. CKD was ranked 27th in the list of causes of total number of deaths worldwide in 1990, but rose to 18th in 2010 according the 2010 Global Burden of Disease Study. Among all patients more than $80 \%$ who receive treatment for kidney failure are in affluent countries with universal access to health care and large elderly populations. Number of cases of kidney failure will increase disproportionately in developing countries, such as China and India, due to increasing number of elderly populations [3]. Currently over 2 million people receive treatment with dialysis or a kidney transplant to stay alive worldwide, yet this number may only represent $10 \%$ of people who are actually need treatment to live. Of the 2 million people receiving treatment for ESRD, the majority are treated in only five countries - the USA, Japan, Germany, Brazil and Italy. But these five countries represent only $12 \%$ of the world population. In about 100 developing countries that make up over $50 \%$ of the world population, there only $20 \%$ of ESRD patient are treated [4].

The number of CKD patients with End Stage Renal Disease (ESRD) is increasing drastically day by day. The treatment procedure of ESRD includes dialysis or kidney transplantation [5]. In developed countries, the treatment of ESRD comprises $2 \%-3 \%$ of total healthcare expenses, while only ESRD patients represent $0.02-0.03 \%$ of the total population [6]. In 2012, the expenditure for ESRD is $\$ 32.9$ billion which is reported by The United States Renal Data System where inpatient services cost $38 \%$, outpatient care cost $34 \%$, physician/supplier costs $21 \%$ and drugs cost 2\% [7]. Around 40, 000 people reportedly die each year from CKD in Bangladesh. Around 20, 000-30, 000 patients suffer from acute kidney failure [8]. Among the kidney patients $100-120$ patients approximately reach ESRD in Bangladesh every year [9].

Though infections of kidney disease are considered less important in the western world [10] but currently obesity, diabetes $[11,12]$ and hypertension $[13,14]$ are indicated as the prime considerations of kidney disease. Cardiovascular disease is also the risk factor for ESRD and sometimes vice versa [15-17]. Again, age is a key predictor of ESRD and $11 \%$ patients without hypertension and diabetes are at stage 3 or worse CKD who are older than 85 years [18]. According to the sex, males with pre-existing diabetes, hypertension and CKD of Asia, Europe, Australia, Africa-Americans and developing countries such as Africa, China and India are at higher risk for End-Stage Renal Disease (ESRD) [19]. One study revealed $16 \%$ prevalence rate of CKD occurs in slums of Dhaka. The percentage was found which belongs to stage-1, stage-2, stage-3,

*Corresponding author: Md Shohel Hossain, Lecturer, Department of Pharmacy, Manarat International University, Dhaka-1212, Bangladesh, Tel: +8802-9022164; Fax: +88-9862226; E-mail: shohel@manarat.ac.bd

Mohammad Safiqul Islam, Professor, Department of Pharmacy, Noakhali Science and Technology University, Noakhali, Bangladesh, Tel: +8801727658650; E-mail: research_safiq@yahoo.com

Received October 24, 2017; Accepted November 30, 2017; Published December 11, 2017

Citation: Hossain MDS, Akter-Uz-Zaman KMD, Amin MN, Ahammed R, Haque MDE, et al. (2017) Association of Biochemical Parameters with Renal Functions of End Stage Renal Disease (ESRD) Patients of Bangladesh. J Bioanal Biomed 9 : 294-298. doi:10.4172/1948-593X.1000196

Copyright: ( $) 2017$ Hossain MDS, et al. This is an open-access article distributed under the terms of the Creative Commons Attribution License, which permits unrestricted use, distribution, and reproduction in any medium, provided the original author and source are credited. 
stage- 4 and stage- 5 diseases are respectively $1.3 \%, 3.4 \%, 11 \%, 0.3 \%$ and $0.1 \%$ [20]. Another study revealed $17.4 \%$ prevalence rate of CKD in Savar, Dhaka. And the percentage was recorded to belong to stage-1, stage-2, stage- 3 , stage- 4 and stage-5 (ESRD) diseases are respectively $1.7 \%, 2.1 \%, 13.1 \%, 0.3 \%$ and $0.2 \%$ [21]. As dialysis and kidney transplantation are very expensive so early detection and intervention are the best strategies for ESRD treatment [16].

The present study is undertaken to evaluate the estimation of renal function of patients with end stage renal disease (ESRD) and also to investigate the correlation between the studied biochemical parameters.

\section{Materials and Methods}

\section{Study design and data collection}

The study protocol was approved by the ethical approval committee of Kidney Foundation Hospital and Research Institute, Dhaka, Bangladesh. This was a case-control study carried out between January, 2016 to December, 2016 consisting of 500 patients with ESRD and 500 healthy volunteers as controls. Demographic data was collected with a well-designed questionnaire by regularly attending in Kidney Foundation Hospital and Research Institute and clinical data were obtained by lab analysis. Before data collection, we conducted a pilot study with a few patients by structured questionnaires to set the variables of the study. According to the purpose of the study, the necessary modification was done in the questionnaires before conducting the final study. Ethical clearance was obtained from the ethical review board of the institution. The purpose of the survey was informed to each subject prior inclusion into the study. Respondents were included in the study having a high level of creatinine than normal and GFR $\leq 15 \mathrm{ml} / \mathrm{min} / 1.73 \mathrm{~m}^{2}$. The healthy volunteer creatinine level will be more than $90 \mathrm{ml} / \mathrm{min} / 1.73 \mathrm{~m}^{2}$. The patients who disagreed to donate blood were excluded from the study.

\section{Blood sample collection}

$5 \mathrm{~mL}$ venous blood sample using a plastic syringe fitted with a sterile stainless steel needle was collected from each patient and control. Before collecting blood, each patient did overnight fasting which is about eight hours. Collected blood samples were taken in a metal-free sterile tube, allowed to clot at room temperature for half an hour and then centrifuged at $3000 \mathrm{rpm}$ for $15 \mathrm{~min}$ to extract the serum. The extracted serum was taken in an eppendorf, analyzed for serum ions and creatinine immediately. To avoid the possible interference in the test reading, all the steps were performed in dust-free environment.

\section{Chemicals and reagents}

The chemicals used for the study were of analytical grade from commercially available company.

\section{Analytical procedure}

A series of coupled enzymatic reactions were carried out to assess the creatinine level including creatininase enzymatic conversion of creatinine into the product creatine which itself is converted to sarcosine by creatineamidinohydrolase (creatinase), followed by oxidation of sarcosine by sarcosine oxidase (SOD) producing hydrogen peroxide. Finally the hydrogen peroxide was quantified at $550 \mathrm{~nm}$ by the formation of a colored dye in the presence of peroxidase. All measurements were performed using an Olympus AU 400 analyzer [22]. Serum sodium, potassium and chloride were measured by ion selective electrode (ISE) method in the Beckman Coulter AU auto analyzer [23-25]. Blood urea nitrogen was assessed by enzymatic methods where the enzyme urease converts urea to ammonia and carbonic acid, which are proportional to the concentration of urea in the sample [26]. Estimation of Serum uric acid was done by uricase method [27]. Serum calcium was estimated by the nephelometric method of Lyman [28].

\section{Statistical analysis}

Statistical analysis was performed using statistical software package SPSS version 22.0 (SPSS, Inc., Chicago, IL). All data were expressed as mean \pm standard error mean (mean \pm SME). Pearson's correlation analysis was used to find the interrelation between the various biochemical parameters.

\section{Results}

\section{Anthropometric and clinical characteristics of subjects}

The mean value of systolic and diastolic blood pressure (SBP and DBP respectively) were $150.23 \pm 1.89 \mathrm{mmHg}$ and $84.43 \pm 1.19 \mathrm{mmHg}$ for patient group and $130.00 \pm 1.84 \mathrm{mmHg}$ and $83.05 \pm .976 \mathrm{mmHg}$ for the healthy control group respectively. The average GFR (Glomerular filtration rate) was calculated $6.90 \pm 1.62$ and $98.07 \pm 3.16$ in patient and control groups respectively which has been indicated in Tables 1 and 2. Sociodemographic data is given below.

\section{Different serum composition profile}

The serum creatinine level was found $872.17 \pm 20.17 \mu \mathrm{mol} / \mathrm{L}$ and $77.89 \pm 1.69 \mu \mathrm{mol} / \mathrm{L}$ in patient and control groups respectively. The BUN was $31.42 \pm 1.38 \mathrm{mmol} / \mathrm{L}$ and $6.08 \pm 1.09 \mathrm{mmol} / \mathrm{L}$ in patients and control groups respectively. The serum uric acid, serum sodium, serum chloride, serum potassium, serum calcium was found $506.51 \pm 7.89$, $132.74 \pm .32,98.98 \pm .39,2.05 \pm .05,2.25 \pm .05 \mu \mathrm{mol} / \mathrm{L}$ respectively in

\begin{tabular}{|c|c|c|}
\hline Variables & Patient group & Control group \\
\hline Age years (Mean \pm SEM) & $51.60 \pm 1.39$ & $49.38 \pm 1.24$ \\
\hline \multicolumn{3}{|l|}{ Sex } \\
\hline Male & 270 & 230 \\
\hline Female & 230 & 215 \\
\hline \multicolumn{3}{|l|}{ Area of residence } \\
\hline Rural & 155 & 125 \\
\hline Urban & 345 & 375 \\
\hline \multicolumn{3}{|l|}{ Taking high amount of meat } \\
\hline Yes & 280 & 70 \\
\hline No & 220 & 430 \\
\hline \multicolumn{3}{|l|}{ Taking high amount of pain killer } \\
\hline Yes & 210 & 35 \\
\hline No & 290 & 465 \\
\hline Taking of antihypertensive drug & & 5 \\
\hline Yes & 160 & 50 \\
\hline No & 340 & 450 \\
\hline \multicolumn{3}{|l|}{ Occupation } \\
\hline Unemployed & 40 & 25 \\
\hline Farmer & 40 & 45 \\
\hline Service & 50 & 20 \\
\hline Business & 120 & 160 \\
\hline Housewife & 250 & 250 \\
\hline \multicolumn{3}{|l|}{ Education } \\
\hline Illiterate & 200 & 190 \\
\hline Primary & 160 & 180 \\
\hline Secondary & 100 & 110 \\
\hline Higher study & 40 & 20 \\
\hline
\end{tabular}

Table 1: Sociodemographic data of ESRD and control patient. 
Citation: Hossain MDS, Akter-Uz-Zaman KMD, Amin MN, Ahammed R, Haque MDE, et al. (2017) Association of Biochemical Parameters with Renal Functions of End Stage Renal Disease (ESRD) Patients of Bangladesh. J Bioanal Biomed 9: 294-298. doi:10.4172/1948-593X.1000196

patient and $303.05 \pm 7.01,140.15 \pm .30,103.21 \pm .31,3.97 \pm .04$ and 2.27 $\pm .016 \mu \mathrm{mol} / \mathrm{L}$ in control groups respectively (Table 3).

To establish correlation between different parameters these data were further analyzed. The correlation was established between GFR, BUN and creatinine with different parameters (Table 4). The statistical data showed a negative correlation between SBP and GFR $\left(r=-0.091^{*}\right.$, $\mathrm{p}=0.039)$, DBP and GFR ( $\left.\mathrm{r}=-0.118^{* *}, \mathrm{p}=0.008\right)$, serum creatinine and GFR $\left(r=-0.753^{* *}, p=0.000\right)$, BUN and GFR $\left(r=-0.217^{* *}, p=0.000\right)$, serum uric acid and GFR ( $r=-0.142, p=0.000)$, serum sodium and BUN $(r=-$ 0.011, $\mathrm{p}=0.797)$, serum chloride and GFR $(\mathrm{r}=-0.057, \mathrm{p}=0.197)$, serum potassium and GFR $(\mathrm{r}=-0.300, \mathrm{p}=0.002)$, serum potassium and GFR $\left(\mathrm{r}=-0.264^{* *}, \mathrm{p}=0.000\right)$, serum calcium and $\mathrm{GFR}(\mathrm{r}=-0.023, \mathrm{p}=0.605)$, serum sodium and creatinine $(r=-0.030, p=0.494)$, Serum calcium and creatinine $(\mathrm{r}=-0.048, \mathrm{p}=284)$, Age and creatinine $(\mathrm{r}=-0.235, \mathrm{p}=0.000)$, Age and BUN ( $\mathrm{r}=-0.016, \mathrm{p}=0.720)$ but a positive correlation between SBP and BUN $(r=0.025, p=0.578)$, DBP and BUN $(r=0.053, p=0.234)$, Serum creatinine and BUN $\left(r=0.234^{* *}, p=0.000\right)$, serum uric acid and BUN ( $\left.r=0.107^{*}, p=0.016\right)$, serum sodium and GFR $(r=0.005, p=0.906)$, serum chloride and BUN $(\mathrm{r}=0.012, \mathrm{p}=0.794)$, serum potassium and $\operatorname{BUN}(r=0.029, p=0.517)$, serum calcium and BUN $\left(r=0.270^{* *}, p=0.000\right)$, SBP and creatinine $(\mathrm{r}=0.026, \mathrm{p}=0.559), \mathrm{DBP}$ and creatinine $\left(\mathrm{r}=0.152^{* *}\right.$, $\mathrm{p}=0.001), \mathrm{BUN}$ and creatinine $\left(\mathrm{r}=0.234^{* *}, \mathrm{p}=0.000\right)$, serum uric acid and creatinine $\left(\mathrm{r}=0.179^{* *}, \mathrm{p}=0.000\right)$, serum chloride and creatinine $(\mathrm{r}=0.061, \mathrm{p}=0.166)$, Serum potassium and creatinine $\left(\mathrm{r}=0.230^{* *}\right.$, $\mathrm{p}=.000)$ Age and GFR $\left(\mathrm{r}=0.114^{* *}, \mathrm{p}=0.010\right)$ in patient group.

\section{Discussion}

Several international studies conducted in Japan, France, Iran and Korea shows that ESRD dramatically increases with aging particularly after the age of 50 in both genders and males develop ESRD more than females [29-31].

In our study we found that there is a negative correlation between age and GFR which means that ESRD is increased with age because with aging GFR is decreased.

One study showed that there is a significant association between patients who have diabetes mellitus and hypertensive with the onset of ESRD. This can be narrated on the light of rapid urbanization, transformation into sedentary life style, increase in prevalence and incidence in diabetes mellitus and hypertension. When a patient suffers from theses chronic disease (diabetes mellitus, hypertension

\begin{tabular}{|c|c|c|c|c|}
\hline Parameters & $\begin{array}{c}\text { Reference } \\
\text { value }(\mathbf{m m H g})\end{array}$ & Patient group & Control group & P-value \\
\hline SBP $(\mathrm{mm} \mathrm{Hg})$ & $<140$ & $150.23 \pm 1.89$ & $130.00 \pm 1.84$ & $<0.05$ \\
\hline DBP $(\mathrm{mm} \mathrm{Hg})$ & $<90$ & $84.43 \pm 1.19$ & $83.05 \pm .97$ & $<0.05$ \\
\hline GFR $\left(\mathrm{ml} / \mathrm{min} / 1.73 \mathrm{~m}^{2}\right)$ & $>90$ & $6.90 \pm 1.62$ & $98.07 \pm 3.16$ & $<0.05$ \\
\hline
\end{tabular}

$\mathrm{p}<0.05$ when compared to control

Table 2: Clinical data of study population.

\begin{tabular}{|c|c|c|c|c|}
\hline Parameters & $\begin{array}{c}\text { Reference } \\
\text { value }\end{array}$ & ESRD patient & $\begin{array}{c}\text { Control } \\
\text { group }\end{array}$ & P-value \\
\hline Serum creatinine $(\mu \mathrm{mol} / \mathrm{L})$ & $63.6-110.5$ & $872.17 \pm 20.17$ & $77.89 \pm 1.69$ & $<0.05$ \\
\hline BUN $(\mathrm{mmol} / \mathrm{L})$ & $3.2-7.4$ & $31.42 \pm 1.38$ & $6.08 \pm 1.09$ & $<0.05$ \\
\hline Serum uric acid $(\mu \mathrm{mol} / \mathrm{L})$ & $210-420$ & $506.51 \pm 7.89$ & $303.05 \pm 7.01$ & $<0.05$ \\
\hline Serum sodium $(\mu \mathrm{mol} / \mathrm{L})$ & $135-146$ & $132.74 \pm .32$ & $140.15 \pm .30$ & $<0.05$ \\
\hline Serum chloride $(\mu \mathrm{mol} / \mathrm{L})$ & $97-106$ & $98.98 \pm .39$ & $103.21 \pm .31$ & $<0.05$ \\
\hline Serum potassium $(\mu \mathrm{mol} / \mathrm{L})$ & $3.5-5.3$ & $2.05 \pm .05$ & $3.97 \pm .04$ & $<0.05$ \\
\hline Serum calcium $(\mu \mathrm{mol} / \mathrm{L})$ & $2.1-2.55$ & $2.25 \pm .05$ & $2.27 \pm .01$ & $<0.05$ \\
\hline
\end{tabular}

Table 3: Serum composition profile of the study population.

\begin{tabular}{|c|c|c|c|c|}
\hline \multirow[t]{2}{*}{ Parameter } & \multicolumn{2}{|c|}{ Patient group } & \multicolumn{2}{|c|}{ Control group } \\
\hline & $r$ & $\mathbf{p}$ & $\mathbf{r}$ & $\mathbf{p}$ \\
\hline SBP and GFR & $-0.091^{*}$ & 0.039 & -0.097 & 0.335 \\
\hline SBP and BUN & 0.025 & 0.578 & -0.025 & 0.808 \\
\hline DBP and GFR & $-0.118^{* *}$ & 0.008 & 0.073 & 0.469 \\
\hline DBP and BUN & 0.053 & 0.234 & 0.036 & 0.725 \\
\hline Serum creatinine and GFR & $-0.753^{* *}$ & 0.000 & $-0.240^{*}$ & 0.016 \\
\hline Serum creatinine and BUN & $0.234^{* *}$ & 0.000 & $0.398^{* *}$ & 0.000 \\
\hline BUN and GFR & $-0.217^{* *}$ & 0.000 & $0.538^{*+}$ & 0.000 \\
\hline Serum uric acid and GFR & $-0.142^{* *}$ & 0.000 & 0.057 & 0.557 \\
\hline Serum uric acid and BUN & $0.107^{*}$ & 0.016 & 0.100 & 0.322 \\
\hline Serum sodium and GFR & 0.005 & 0.906 & -0.089 & 0.378 \\
\hline Serum sodium and BUN & -0.011 & 0.797 & -0.033 & 0.744 \\
\hline Serum chloride and GFR & -0.057 & 0.197 & -0.061 & 0.549 \\
\hline Serum chloride and BUN & 0.012 & 0.794 & 0.058 & 0.564 \\
\hline Serum potassium and GFR & $-0.264^{* *}$ & 0.000 & 0.037 & 0.713 \\
\hline Serum potassium and BUN & 0.029 & 0.517 & 0.137 & 0.175 \\
\hline Serum calcium and GFR & -0.023 & 0.605 & 0.131 & 0.194 \\
\hline Serum calcium and BUN & $0.270^{* *}$ & 0.000 & 0.132 & 0.192 \\
\hline SBP and creatinine & 0.026 & 0.559 & 0.013 & 0.896 \\
\hline DBP and creatinine & $.152^{* *}$ & 0.001 & -0.098 & 0.331 \\
\hline BUN and creatinine & $.234^{* *}$ & 0.000 & $0.398^{* *}$ & 0.000 \\
\hline Serum uric acid and creatinine & $.179^{* *}$ & 0.000 & $0.242^{*}$ & 0.015 \\
\hline Serum sodium and creatinine & -.030 & 0.494 & 0.058 & 0.568 \\
\hline Serum chloride and creatinine & .061 & 0.166 & 0.168 & 0.096 \\
\hline $\begin{array}{l}\text { Serum potassium and } \\
\text { creatinine }\end{array}$ & $.230^{* *}$ & 0.000 & 0.167 & 0.096 \\
\hline Serum calcium and creatinine & -.048 & 0.284 & -0.086 & 0.396 \\
\hline Age and GFR & $0.114^{*}$ & 0.010 & -0.100 & 0.322 \\
\hline Age and creatinine & $-0.235^{* *}$ & 0.000 & $0.252^{*}$ & 0.011 \\
\hline Age and BUN & -0.016 & 0.720 & 0.087 & 0.389 \\
\hline
\end{tabular}

"indicates $p<0.01$, "indicates $p<0.05$ when compared to control

Table 4: Correlation between BUN, GFR and creatinine of patient and control group.

and cardiovascular diseases) are more likely to get kidney failure. Changes in the style of living, increase in incident chronic diseases lead to a high complication. There is a significant association between Glomerulonephritis and other urinary tract infection with incident of ESRD which was confirmed by several studies conducted in different countries [32-36]. The associations of different cut-off values of serum creatinine with the risks of death from any causes, particularly with the cardiovascular events have been examined in several studies [3741]. Most but not all of these studies [42,43] have found increased risks of cardiovascular disease with higher serum creatinine levels. Since serum creatinine levels are not linearly associated with GFR [44], the predictive equations such as the Cockcroft-Gault equation for creatinine clearance [45] and the MDRD equation for estimated GFR [46] has been proposed as a more accurate means of estimating the GFR in populations [18].

Relatively very few studies have evaluated the risk of outcomes in the general population. One research report showed that there is $68 \%$ percent increase in the risk of death from any cause associated with an estimated GFR of less than $70 \mathrm{ml} / \mathrm{min} / 1.73$ sq. $\mathrm{m}$, as compared with an estimated GFR of at least $90 \mathrm{ml} / \mathrm{min} / 1.73$ sq. m. [47]. In our study, we have found that GFR is associated with serum creatinine level. There is a negative correlation between serum creatinine and GFR both in patient and control groups. The patient group had higher creatinine level and lower GFR but the control group had lower serum creatinine level and higher GFR (more than $90 \mathrm{ml} / \mathrm{min} / 1.73$ sq. m). 
Citation: Hossain MDS, Akter-Uz-Zaman KMD, Amin MN, Ahammed R, Haque MDE, et al. (2017) Association of Biochemical Parameters with Renal Functions of End Stage Renal Disease (ESRD) Patients of Bangladesh. J Bioanal Biomed 9: 294-298. doi:10.4172/1948-593X.1000196

Diabetes and hypertension are the leading causes of ESRD in all developed and many developing countries. But in countries of Asia and sub-Saharan Africa, glomerulonephritis and unknown causes of CKD are more common. The burden of disease moving away from infections towards chronic lifestyle-related diseases increased life expectancy and decreased birth rates in developed countries [48]. In contrast, inadequate supply of safe water, secondary to poor sanitation and high concentrations of disease-transmitting vectors are the key factors for the outgrowth of ESRD in low-income countries [49]. The burden of ESRD in developing countries is also contributed by environmental pollution, pesticides, analgesic abuse, herbal medications and use of unregulated food additives [50]. Due to the acceleration of globalization and urbanization the transition of ESRD have accelerated in the South Asian and Latin American countries together with and increasing prevalence of lifestyle disorders, such as diabetes and hypertension [51,52]. Studies showed that $42 \%$ of CKD cases occurred in patients without diabetes while $39 \%$ of cases occurred in those patients with undiagnosed diabetes or pre-diabetes. A substantial proportion of adults with undiagnosed diabetes had evidence of kidney disease and kidney function decline [53].

In our research we found that there is a relationship between hypertension and kidney disease. There is a positive correlation between SBP and creatinine and negative correlation between SBP and GFR on kidney patient. So it indicates that there is a close relationship with SBP and kidney disease. Positive correlation between SBP and serum creatinine means the higher serum creatinine level leads to higher SBP while negative correlation between SBP and GFR means the higher SBP is the result of lower GFR. So hypertension is a vital cause for kidney disease.

The standard limit of serum potassium is believed to arise only at the end stage of CKD [54]. Furthermore the linear relationship between potassium and parathyroid hormone $(\mathrm{PTH})$ observed that excess PTH increases basal levels of cytosolic calcium. Cytosolic calcium affects the permeability of the cellular membrane to potassium. So that extra renal disposal of potassium is decreased in case of kidney disease [55]. Potassium stimulates the pancreas to release insulin [56], which is an important regulator of extra renal disposition of potassium. Since glucose-induced insulin secretion is impaired by secondary hyperparathyroidism (SHPT) of CKD [57], which is likely to interfere with potassium-induced insulin secretion. So it could result in the derangement of the extra renal disposition of potassium. Due to impaired intestinal absorption and phosphate retention, serum calcium levels were found to be significantly lower in the cohorts with ESRD than in controls, a finding that is consistent with previously reported observations [58]. Furthermore, as compared to the controls, the kidney patients were about 8 times at risk of developing hypocalcaemia. Excess PTH secretion was stimulated by hypocalcaemia [59].

In our study we found that there is a negative correlation between serum potassium and GFR, positive correlation between serum potassium and creatinine in the patient group. But there is a positive correlation between serum potassium and GFR in control group. Here we understand that after ESRD the serum potassium is decreased and for that reason GFR is increased. We also found a negative correlation between serum calcium and creatinine both in patient and control group. Hypocalcaemia can cause higher serum creatinine level. Therefore hypocalcaemia is also dangerous for the ESRD patient.

\section{Conclusion}

Our study explored that ESRD patient have high level of serum creatinine, blood urea nitrogen, serum uric acid and the low level of serum potassium than the healthy control subjects, all of which may contribute worsening of kidney problem. We thus recommend routine investigation of biochemical parameters of ESRD patient specially serum creatinine to prevent complications of chronic kidney disease.

\section{Acknowledgement}

The author would like to thanks all the participants of the study. The authors are also thankful to all the staff, nurses and physicians of the Kidney Foundation Hospital and Research Institute, Dhaka.

\section{Competing Interests}

The author reports that they have no conflict of interests in this work.

\section{References}

1. National Kidney Foundation (2002) K/DOQI clinical practice guidelines for chronic kidney disease: Evaluation, classification and stratification. Am J Kidney Dis 39: S11-S12.

2. http://www.worldkidneyday.org/faqs/chronic-kidney-disease

3. Jha V, Garcia-Garcia G, Iseki K, Li Z, Naicker S, et al. (2013) Chronic kidney disease: Global dimension and perspectives. Lancet 382: 260-272.

4. Couser WG, Remuzzi G, Mendis S, Tonelli M (2011) The contribution of chronic kidney disease to the global burden of major noncommunicable diseases. Kidney Int 80: 1258-1270.

5. Lysaght MJ (2002) Maintenance dialysis population dynamics: Current trends and long-term implications. J Am Soc Nephrol 13: S37-S40.

6. Levey AS, Atkins R, Coresh J, Cohen EP, Collins AJ, et al. (2007) Chronic kidney disease as a global public health problem: Approaches and initiatives-a position statement from Kidney Disease Improving Global Outcomes. Kidney Int 72: 247-259.

7. Yan G, Norris KC, Greene T, Yu AJ, Ma JZ, et al. (2014) Race/ethnicity, age and risk of hospital admission and length of stay during the first year of maintenance hemodialysis. Clin J Am Soc Nephrol 9: 1402-1409.

8. Huda MN, Alam KS (2012) Prevalence of chronic kidney disease and its association with risk factors in disadvantageous population. Int $\mathrm{J}$ Nephrol 72: 201-206.

9. Saha M, Faroque MO, Alam KS, Alam MM, Ahmed S (2012) Chronic Kidney Disease specific cardiovascular risk factors among non dialytic patients with Chronic Kidney Disease stage-V: An experience of a specialized hospital. Bangladesh Med Res Counc Bull 38: 18-22.

10. Barsoum RS (2006) Chronic kidney disease in the developing world. New Eng J Med 354: 997-999

11. Gregg EW, Cheng YJ, Cadwell BL, Imperatore G, Williams DE, et al. (2005) Secular trends in cardiovascular disease risk factors according to body mass index in US adults. JAMA 293: 1868-1874.

12. Mokdad AH, Ford ES, Bowman BA, Dietz WH, Vinicor F, et al. (2003) Prevalence of obesity, diabetes and obesity-related health risk factors, 2001. JAMA 289: 76-79.

13. Hajjar I, Kotchen TA (2003) Trends in prevalence, awareness, treatment and control of hypertension in the United States, 1988-2000. JAMA 290: 199-206.

14. Mann JF, Gerstein HC, Pogue J, Bosch J, Yusuf S (2001) Renal insufficiency as a predictor of cardiovascular outcomes and the impact of ramipril: The HOPE randomized trial. Ann Intern Med 134: 629-636.

15. De Zeeuw D, Hillenge HL, De Jong PE (2005) The Kidney, a cardiovascular risk marker and a new target for therapy. Kidney Int 68: 25-29.

16. Sarnak MJ, Levey AS, Schoolwerth AC, Coresh J, Culleton B, et al. (2003) Kidney disease as a risk factor for development of cardiovascular disease: A statement from the American Heart Association Councils on Kidney in Cardiovascular Disease, High Blood Pressure Research, Clinical Cardiology and Epidemiology and Prevention. Hypertension 42: 1050-1065. 
Citation: Hossain MDS, Akter-Uz-Zaman KMD, Amin MN, Ahammed R, Haque MDE, et al. (2017) Association of Biochemical Parameters with Renal Functions of End Stage Renal Disease (ESRD) Patients of Bangladesh. J Bioanal Biomed 9: 294-298. doi:10.4172/1948-593X.1000196

17. Levey AS, Bosch JP, Lewis JB, Greene T, Rogers N, et al. (1999) A more accurate method to estimate glomerular filtration rate from serum creatinine: A new prediction equation. Modification of Diet in Renal Disease Study Group. Ann Intern Med 130: 461-470.

18. Bakris GL, Ritz E (2009) The message for World Kidney Day 2009: Hypertension and kidney disease: A marriage that should be prevented. J Clin Hypertens 11: 144-147.

19. Hasan MJ, Kashem MA, Rahman MH, Qudduhush R, Rahman M (2013) Prevalence of chronic kidney disease (CKD) and identification of associated risk factors among rural population by mass screening. CBMJ 1: 20-26.

20. Hasan MJ, Muqueet A, Sharmeen A, Rahman M, Ahmed TU, (2012) Prevalence of Diabetes mellitus, Hypertension and Proteinuria in a Rural area of Bangladesh. CBMJ 1: 8-13.

21. Coresh J, Astor BC, Greene T, Eknoyan G, Levey AS (2003) Prevalence of chronic kidney disease and decreased kidney function in the adult US population: Third National Health and Nutrition Examination Survey. Am J Kidney Dis 41: 1-12.

22. Myers GL, Miller WG, Coresh J, Fleming J, Greenberg N, et al. (2006) Recommendations for improving serum creatinine measurement: A report from the Laboratory Working Group of the National Kidney Disease Education Program. Clin Chem 52: 5-18

23. Jia K, Zhang C, Huang X, Wang L, Hao X, et al. (2015) Reference Intervals of Serum Sodium, Potassium, and Chlorine in Chinese Han Population and Comparison of Two ISE Methods. J Clin Lab Anal 29: 226-34.

24. Tietz N (1976) Fundamentals of clinical chemistry. $6^{\text {th }}$ edn. WB Saunders Company, Philadelphia, USA.

25. Young DS, Pestaner LC, Gibberman V (1975) Effects of drugs on clinical laboratory tests. Clin Chem 21: 1D-432D.

26. Ruiyang Zhang, Weiyun Zhu, Shengyong Mao (2016) High-concentrate feeding upregulates the expression of inflammation-related genes in the ruminal epithelium of dairy cattle. J Anim Sci Biotechnol 7: 42

27. Mac Donald RP (2013) Standard Methods of Clinical Chemistry: The American Association of Clinical Chemists. $1^{\text {st }}$ edn. USA.

28. Kramer B, Howland J (1920) Method for determination of calcium in small quantities of blood serum. J Biol Chem 43: 35-40.

29. Afshar R, Sanavi S, Salimi J (2007) Epidemiology of chronic renal failure in Iran: A four year single- center experience. Saudi J Kidney Dis Transpl 18: 191-194.

30. Couchoud C, Pozet N, Labeeuw M, Pouteil-Noble C (1999) Screening early renal failure: Cut-off values for serum creatinine as an indicator of renal impairment. Kidney International 55: 1878-1884.

31. Nagata M, Ninomiya T, Doi Y, Yonemoto K, Kubo M, et al. (2010) Trends in the prevalence of chronic kidney disease and its risk factors in a general Japanese population: The Hisayama Study. Nephrol Dial Transplant 5: 342-252.

32. Abdallah S, Ahmad AT, Batiehal A, Ajlouni K (2007) Diabetes mellitus: The leading cause of haemodialysis in Jordan. East Medit Health J 13: 803-809.

33. Vupputuri S, Soucie M, Clellan W (2004) History of Kidney Stones as a Possible Risk Factor for Chronic Kidney Disease. Ann Epidemiol 3: 222-228.

34. Soyibo AK, Barton EN (2007) Report from the Caribbean renal registry, 2006 West Indian Med J 5: 45-51.

35. Afifi A, Karim MA (1999) Renal replacement therapy in Egypt: first annual report of the Egyptian Society of Nephrology. East Medit Health J 5: 1023-1029.

36. Alalawi F, Ahmed M, AlNour H, Noralla M, Alhadari A (2017) Epidemiology of end-stage renal disease in Dubai: Single-center data. Saudi J Kidney Dis Transpl 28: 1119-1125.

37. Go AS, Chertow GM, Fan D, McCulloch CE, Hsu CY (2004) Chronic kidney disease and the risks of death, cardiovascular events and hospitalization. N Engl J Med 351: 1296-1305.
38. Go AS, Fang MC, Udaltsova N, Chang Y, Pomernacki NK et al (2009) Impact of proteinuria and glomerular filtration rate on risk of thromboembolism in atria fibrillation: The anticoagulation and risk factors in atrial fibrillation (ATRIA) study. Circulation 119: 1363-1369.

39. Ruilope LM, Salvetti A, Jamerson K, Hansson L, Warnold I, et al. (2001) Rena function and intensive lowering of blood pressure in hypertensive participants of the hypertension optimal treatment (HOT) study. J Am Soc Nephrol 12: 218-225.

40. Sarafidis PA, Bakris GL (2006) Microalbuminuria and chronic kidney disease as risk factors for cardiovascular disease. Nep Dial Transp 21: 2366-2374.

41. Drey N, Roderick P, Mullee M, Rogerson M (2003) A population-based study of the incidence and outcomes of diagnosed chronic kidney disease. Am J Kidney Dis 42: 677-684.

42. Culleton BF, Larson MG, Wilson PW, Evans JC, Parfrey PS, et al (1999) Cardiovascular disease and mortality in a community-based cohort with mild renal insufficiency. Kidney Int 56: 2214-2219.

43. Garg AX, Clark WF, Haynes RB, House AA (2002) Moderate renal insufficiency and the risk of cardiovascular mortality: Results from the NHANES I. Kidney In 61: 1486-1494.

44. Stevens LA, Coresh J, Greene T, Levey AS (2006) Assessing kidney functionmeasured and estimated glomerular filtration rate. N Engl J Med 354: 2473-2483.

45. Levey AS, Coresh J, Greene T, Stevens LA, Zhang YL, et al. (2006) Using standardized serum creatinine values in the modification of diet in renal disease study equation for estimating glomerular filtration rate. Ann Intern Med 145: 247-254.

46. Levey AS, Greene T, Kusek JW, Beck GJ (2000) A simplified equation to predict glomerular filtration rate from serum creatinine. J Am Soc Nephrol 11 : 155-158.

47. Driver TH, Scherzer R, Peralta CA, Tien PC, Estrella MM, et al. (2013) Comparisons of creatinine and cystatin $\mathrm{C}$ for detection of kidney disease and prediction of all-cause mortality in HIV-infected women. AIDS 27: 2291-2299.

48. Engelgau MM, El-Saharty S, Kudesia P, Rajan V, Rosenhouse $S$, et al (2011) Capitalizing on the demographic transition: Tackling noncommunicable diseases in South Asia. Directions in development; human development. Washington DC World Bank 1: 62260.

49. Ayodele OE, Alebiosu CO (2010) Burden of chronic kidney disease: An international perspective. Adv Chr Kid Dis 17: 215-224.

50. Jha V (2004) End-stage renal care in developing countries: The India experience. Ren Fail 26: 201-208

51. Agyei-Mensah S, Aikins AD (2010) Epidemiological transition and the double burden of disease in Accra, Ghana. J of Urban Health 87: 879-897.

52. Frenk J, Frejka T, Bobadilla JL, Stern C, Lozano R, et al. (1991) The epidemiologic transition in Latin America. Bol Oficina Sanit Panam 111: 485-496.

53. American Diabetes Association (2013) Standards of medical care in diabetes--2013. Diabetes Care 36: S11-66.

54. Allon M (1995) Hyperkalemia in end-stage renal disease: Mechanisms and management. J Am Soc Nephrol 6: 1134-1142.

55. Owiredu W, Ephraim R, Amidu B, Laing E (2012) Relationship between parathyroid hormone and electrolytes in chronic kidney disease. J Med Res 1: 103-111.

56. Bia MJ, De Fronzo RA (1981) Extrarenal potassium homeostasis. Am J Physio 240: F257-F268.

57. Fadda GZ, Hajjar SM, Perna AF, Zhou XJ, Lipson LG, et al. (1991) On the mechanism of impaired insulin secretion in chronic renal failure. J Clin Invest 87: 255-261.

58. Moe SM (2016) Calcium Homeostasis in Health and in Kidney Disease. Compr Physiol 6: 1781-1800.

59. Yamamoto M, Igarashi T, Muramatsu M, Fukagawa M, Motokura T, et al. (1989) Hypocalcemia increases and hypercalcemia decreases the steady-state level of parathyroid hormone messenger RNA in the rat. J Clin Invest 83: 1053-1056. 